PRZEMYSŁAW GĄSIOREK

ORCID 0000-0001-9611-8975

Uniwersytet im. Adama Mickiewicza

$w$ Poznaniu

\title{
OD MAŁEGO „DYZIA" \\ DO DOROSŁEGO „RYCERZA Z LA MANCHY”. ANALIZA PROBLEMU MARZYCIELSTWA U DZIECI \\ I MEODZIEŻY \\ Z PERSPEKTYWY KULTUROWO-HISTORYCZNEJ \\ TEORII ROZWOJU
}

\begin{abstract}
AвSTRAct. Gąsiorek Przemysław, Od małego "Dyzia" do dorosłego "rycerza z La Manchy". Analiza problemu marzycielstwa u dzieci i młodzieży z perspektywy kulturowo-historycznej teorii rozwoju [From a Small "Dyzio" to an adult "knight from La Mancha". Analysis of the Problem of Daydreaming in Children and Adolescents from the Perspective of Cultural-Historical Theory of Development]. Studia Edukacyjne nr 60, 2021, Poznań 2021, pp. 87-101. Adam Mickiewicz University Press. ISSN 1233-6688. DOI: $10.14746 /$ se.2021.60.5
\end{abstract}

This study describes the issue of maladaptive daydreaming. This phenomenon is becoming a contemporary educational problem because it limits the development potential of children and adolescents as well as their interpersonal relations. The field of possible understanding of maladaptive daydreaming in relation to terms related in meaning was outlined, as well as the current attempts at its scientific conceptualization. In my analysis, I go beyond the dualistic understanding of the children's real and imaginary world, referring to the cultural-historical theory of the development of creative imagination as a higher mental function as an internalized system of social relations. From this perspective, the phenomenon of daydreaming in children and adolescents, in relation to reality, is not treated in a dichotomous way, but as a social development situation.

Key words: daydreaming, creative imagination, social situation of development,

\section{Wprowadzenie}

Współcześnie bardzo często można usłyszeć z ust młodych ludzi, jak roztaczają swoje plany o informatycznej, prawniczej lub medycznej karierze zawodowej, gdy jednocześnie grają na komputerze, słuchając głośno muzyki, 
jednocześnie nieustannie przeglądają "memy” lub wysyłają emotikony na kilku czatach równolegle. Na pytanie, dlaczego się nie uczą ważnych dla realizacji ich marzeń przedmiotów w szkole, nie rozwijają potrzebnych do tego kompetencji, nie uczestniczą w spotkaniach z osobami o podobnych zainteresowaniach, odpowiadają: „nie robię tego, bo mi się teraz nie chce, jeszcze zdążęe". Proszeni o wyjaśnienie uzyskania niskiej oceny z klasówki mówią: "nie chciało mi się, gdybym chciał, to bym się nauczył". Postawę tę w trafny sposób oddał J. Tuwim w swoim wierszu „Dyzio marzyciel”: „Położył się Dyzio na łące... I jadł... I jadł... I jadł”. Pojawiające się kolejne negatywne oceny i opinie, jakie dziecko słyszy na swój temat, niestety nie są przez nie odbierane jako pomoc w stworzeniu bardziej realnej oceny siebie, swoich możliwości i obiektywnej oceny rzeczywistości. Paradoksalnie, nieprzystająca do marzeń rzeczywistość i potwierdzające to doświadczenia sprzyjają dalszemu „zatapianiu” w „nierzeczywistej rzeczywistości”, wraz z czym następuje pogłębienie izolacji społecznej. Przypomina to dobrze opisany przez M. Cervantesa przy padek „rycerza”, który „po zderzeniu z twardą rzeczywistością” dostrzega, że nie walczy z olbrzymami, lecz z wiatrakami. Don Kichot odnajduje jednak zawsze winnego takiego stanu rzeczy, między innymi w osobie złego czarnoksiężnika, który ciągle źle mu życzy i robi mu coś na przekór.

Tymi „złymi” i „nieprzychylnymi” naszemu „walecznemu Don Kichotowi” są oczywiście najczęściej nauczyciele, rodzice lub inni dorośli, mniej lub bardziej jednoznacznie negatywnie odnoszący się do sytuacji, w jakiej on się znajduje. Lecz o ile wiersz J. Tuwima, jak i powieść M. Cervantesa, niejednokrotnie wywołują na twarzach czytelników uśmiech, o tyle napotkanie takiej sytuacji w praktyce pedagogicznej nie stanowi już tak pozytywnego doświadczenia. Konfrontacja w szkole lub w domu z dzieckiem, które w taki sposób odnosi się do rzeczywistości i innych ludzi, może doprowadzić rodziców i nauczycieli do złości, niechęci, rezygnacji, a nawet rozpaczy. W równie trudnej sytuacji jest i samo dziecko, które mniej lub bardziej, ale uświadamia sobie swoje ograniczenia. Kształtuje to jego niską samoocenę, brak poczucia sprawstwa, panowania nad sobą, swoją wyobraźnią i otaczającą je rzeczywistością. Wszystko to generuje coraz większy lęk przed innymi, przed światem i przed przyszłością. Zamiast wyciągnąć wnioski z przebytych doświadczeń, dzieci te stosują najłatwiejsze rozwiązanie, którym jest „ucieczka” od traumatyzujących doznań w świat marzeń. Współczesną popkulturową egzemplifikacją tego są losy bohaterów ulubionej przez dzieci bajki „Król Lew”, którzy zagłuszają głosy innych, jak i własne myśli, głośnym śpiewem „Hakuna Matata... i już się nie martw, tak cudownie to brzmi".

Mimo że marzycielstwo jest często spotykanym problemem $\mathrm{w}$ praktyce pedagogicznej, to $\mathrm{w}$ polskim piśmiennictwie jest wątkiem prawie nieobecnym. Sam fenomen marzeń jest podejmowany w licznych publikacjach 
M. Piaseckiej ${ }^{1}$ czy A. Kałużnej-Wielobób². Marzycielstwo jest jednak raczej uzupełnieniem innych kategorii, takich jak fantazja dziecięca, zaburzenia uwagi, czy elementem badań nad problemem aspiracji dzieci i młodzieży ${ }^{3}$. Marzycielstwo więc, ze względu na niezwykłą zjawiskowość, jak też jako poważny problem edukacyjny, zasługuje na pogłębioną analizę, zarówno teoretyczną jak i empiryczną. Niniejszy tekst jest eksploracyjną próbą nakreślenia pola rozumienia tegoż fenomenu i uwarunkowań jego występowania. Zostanie to dokonane przede wszystkim z wykorzystaniem założeń i kategorii teoretycznych, wyodrębnionych w ramach kulturowo-historycznego podejścia do rozwoju człowieka.

\section{Marzycielstwo - zakres problemowy pojęcia}

Marzycielstwo jest słownikowo definiowane jako „skłonność do snucia nierealnych planów” lub inaczej „łudzenie się marzeniami”, przy czym ułuda jest określana jako uznanie marzenia lub wyobrażenia za rzeczywistość ${ }^{4}$. Drugim biegunem marzycielstwa byłby zatem realizm, a tym co odróżnia oba te stanowiska jest skrajnie odmienny stosunek do rzeczywistości. Realiści są zaangażowani w świat rzeczywisty, ale bez przekształcającej go wyobraźni, a marzyciele z wyobraźnią, ale bez zdolności włożenia wysiłku w jej realizację. Istotne jest więc postawienie pytania, dlaczego niektórzy są tak skrajnymi realistami, że nie mają marzeń przekraczających i przekształcających rzeczywistość, a z drugiej - dlaczego inni mają bardzo wiele marzeń, ale „nie mają kontaktu z rzeczywistością". Jednych i drugich często określa się osobami „ograniczonymi”. Pierwszych jako tych bez woli do zmiany swojego myślenia o rzeczywistości w której żyją, natomiast drugich jako tych, którzy

${ }^{1}$ M. Piasecka, Otwieranie świata edukacji - w stronę potencjalności, Podstawy Edukacji, 2009, 2, s. 73-88; taże, Marzenia sprawcze i ponadosobiste w perspektywie badan narracyjnych, Podstawy Edukacji, 2012, 5, s. 139-156; taże, Marzenia w narracji autobiograficznej. Między porządkiem a chaosem, Podstawy Edukacji, 2015, 8, s. 199-215; taże, Topoanaliza autobiograficzno-symboliczna jako metoda badania (nie)dokończonych marzeń, Studia Edukacyjne, 2020, 56, s. 401-419; taże, (Geo)poetyka marzenia. Utopia - heterotopia - trzecia przestrzeń, [w:] Utopia a edukacja, t. IV, red. R. Włodarczyk, Wrocław 2020, s. 179-202.

2 A. Kałużna-Wielobób, Typy "marzycielek" wśród kobiet w wieku średnim, Roczniki Psychologiczne, 2009, 12, 2, s. 55-82; taże, Marzenia a cechy osobowości licealistek i studentek, Studia Psychologica: Theoria et praxis, 2012, 12, 1, s. 101-124; taże, Marzenia wspótczesnych kobiet w różnych okresach rozwojowych, Teraźniejszość - Człowiek - Edukacja, 2013, 16, 1(61), s. 109-136.

3 Z. Skorny, Aspiracje młodzieży oraz kierujące nimi prawidtowości, Wrocław 1980; E. Syrek, Aspiracje życiowe młodzieży niedostosowanej spotecznie, Katowice 1986; J. Jarmużek, Uwarunkowania aspiracji edukacyjno-zawodowych człowieka, Acta Universitatis Nicolai Copernici. Pedagogika, 2018, 36, 2, s. 199-221.

${ }^{4}$ W. Doroszewski, Marzycielstwo, b.d., https://sjp.pwn.pl/slowniki/marzycielstwo.html, [dostęp: 15.12.2020]. 
choć myślą nad tym co powinno się zmienić, nie mają jednak na tyle siły, aby ową rzeczywistość zmienić. Pierwsi są ograniczeni, a tym samym zniewoleni tym co realistyczne, zaś ci ostatni nie mogą uwolnić się od swoich wyobrażeń i skonfrontować ich z rzeczywistością. Z perspektywy tejże analizy interesuje nas kwestia jedynie tych ostatnich, zwanych marzycielami.

Za "ojca wszelkiego marzycielstwa" ${ }^{5}$ uznaje się Platona, któremu zawdzięczamy kategorię ideału i idealizmu, czyli pojęć, których „nigdy nie czerpie się ze zmysłów”, lecz są one "pierwowzorami samych rzeczy”. Jemu to właśnie E. Kant zarzucał w swoim dziele pod tytułem Krytyka czystego rozumu, że

Platon opuścił świat zmysłów, gdyż świat ten stawia dla intelektu tak ciasne granice, i puścił się poza nie na skrzydłach idei w pustą przestrzeń czystego intelektu. Nie zauważył, iż przez swe wysiłki nie zdobywa [nowej] drogi; nie znalazł bowiem żadnego oporu, niby podstawy, na której mógłby się oprzeć i do której mógłby użyć swych sił, by poruszyć z miejsca intelekt ${ }^{6}$.

Szczególnymi przykładami tego typu marzycielskich postaw są autorzy wielkich utopii politycznych, filozoficznych, psychologicznych, czy pedagogicznych (Morus, Campanella, Bacon, Rousseau i in.), którzy mimo swego upodobania w rzeczywistości wyobrażonej zdołali ją „,zmaterializować” jedynie w słowach swych dzieł literackich. Tym, co wspólne pozostaje marzycielstwu i utopii jest jednak fakt niemożności ich zrealizowania ${ }^{7}$.

Podobnym do marzycielstwa fenomenem jest prokrastynacja, czyli odraczanie wykonania tego czego się pragnie i do czego się dąży. Zajmują się nią przede wszystkim specjaliści od zarządzania zasobami ludzkimi, konstruujący liczne projekty przeciwdziałania temu zjawisku, w celu usprawnienia działalności swoich przedsiębiorstw, ale też coraz częściej w tę stronę kierują swoją uwagę pedagodzy i psycholodzy ${ }^{8}$.

${ }^{5}$ I. Kant, Co to znaczy orientować się w myśleniu?, Principia, 2012, 2003, 36, s. 7; M. Wesoły, Platon i Arystoteles w ocenie Kanta, Przegląd Filozoficzny. Nowa Seria, 1997, 23, 3, s. 71-72. Pojęcie „die Schwärmerei” z języka niemieckiego na język polski można tłumaczyć jako „marzycielstwo", ,"egzaltowane marzycielstwo" lub "mistyczne filozofowanie”.

${ }^{6}$ M. Wesoły, Platon i Arystoteles w ocenie Kanta, s. 69.

7 J. Szacki, Spotkania z utopia, Warszawa 2000; B. Śliwerski, Utopia edukacyjnych utopii, [w:] Pedagogiczne konteksty społecznych wyobrażeń świata możliwego, t. 2 - Utopia a edukacja, red. R. Włodarczyk, Wrocław 2017, s. 11-16; J. Kozielecki, Smutek spełnionych baśni, Kraków 1985.

${ }^{8}$ K. Markiewicz, Prokrastynacja i prokrastynatorzy. Definicja, etiologia, epidemiologia i terapia, Annales Universitatis Mariae Curie-Skłodowska - Paedagogia-Psychologia, 2019, 31, 3, s. 195; E. Dryll, Prokrastynacja: dlaczego nadal wiemy za mato?, Psychologia Wychowawcza, 2017, 54, s. 152-163; A. Bartczak i in., Prokrastynacja zawodowa jako forma ekologii pracy i jej wspótczesne uwarunkowania, Czasopismo Psychologiczne, 2018, 24, 2; S. Pearlman-Avinion, R. Harduf, Prokrastynacja, perfekcjonizm oraz poczucie umiejscowienia kontroli w kontekście akademickim, Szkoła Specjalna, 2019, 80, s. 108-124. 
W naukach teologicznych znajdujemy zjawisko bliskie marzycielstwu, opisywane jako acedia, którego główną cechą jest stan, w którym rzeczywistość otaczająca człowieka przestaje go pobudzać do działania. Mimo tego, iż ma wolę i pragnienie zaangażowania $\mathrm{w}$ otaczający go świat, to nie potrafi tego zrobić.

W psychologii również spotykamy fenomeny o cechach zbliżonych do marzycielstwa $\mathrm{w}$ postaci dystymii, którą charakteryzuje niski stan pobudzenia emocjonalnego, często uniemożliwiający podejmowanie działań ${ }^{10}$. Zazwyczaj jest to połączone właśnie z fantazjowaniem na temat własnej osoby, dysocjacją i rozbieżnością między "Ja realnym” i „Ja idealnym"11.

Marzycieli w pedagogice uznaje się za osoby znudzone tym, co wokół nich się dzieje, niemające silnej woli, leniwe, "bujające w obłokach”, lub też niepotrafiące skupić swojej uwagi na rzeczach aktualnie istotnych. Najbliższą pojęciowo marzycielstwu kategorię $\mathrm{w}$ pedagogice możemy odnaleźć $\mathrm{w}$ pracy Z. Skornego, poświęconej aspiracjom młodzieży ${ }^{12}$. Opisał on w niej tak zwaną „aspirację życzeniową", w odróżnieniu od „aspiracji działaniowej”, odwołując się między innymi do prac L. Festingera i K. Lewina, C. Rogersa, J. Reykowskiego i W. Łukaszewskiego. Charakteryzuje je istotna różnica między upragnionym stanem idealnym a stanem faktycznym. Kluczową kategorią ich opisu jest stosunek do podejmowanego działania. W pozytywnym sensie stanowią one kontinuum, którego cel daleki jest idealny i wyznaczany przez aspirację życzeniową, ale to aspiracja działaniowa odpowiada za zaangażowanie w cele bliskie i konkretne ${ }^{13}$. Negatywnym aspektem niezależnie funkcjonującej aspiracji życzeniowej, zdaniem Skornego, jest to, że nie przekłada się na działania. Marzenia same w sobie, które są jej główną składową, nie powinny być natomiast uznawane za aspiracje, ponieważ nie uwzględniają obiektywnych uwarunkowań ich spełnienia ${ }^{14}$. Szczególnym przypadkiem

${ }^{9}$ Ł. Stec, Acedia a poszukiwanie nieokreślonego. Między melancholia, nudą a utopia, Młoda Humanistyka, 2019, 14, 1, s. 1-12; M. Jarosz, Acedia jako zagrożenie duchowe, Zeszyty Formacji Katechetów, 2020, 2-3, s. 16-28.

${ }^{10}$ J.N. Butcher, J.M. Hooley, S. Mineka, Psychologia zaburzeń: DSM - 5, Sopot 2020, s. 285303.

${ }^{11}$ L.A. Pervin, O.P. John, Osobowość: teoria i badania, Kraków 2002, s. 199-202.

12 Z. Skorny, Aspiracje młodzieży oraz kierujące nimi prawidłowości, s. 27-30.

${ }^{13}$ Aspiracje działaniowe można współcześnie opisać metodą SMART: Skonkretyzowany (ang. Specific), Mierzalny (ang. Measurable), Osiągalny (ang. Achievable), Istotny (ang. Relevant) Określony w czasie (ang. Time-bound). Aspiracje życzeniowe dobrze oddaje myśl George'a Bernarda Shawa: „Ideały są jak gwiazdy. Jeśli nawet nie możemy ich osiągnąć, to należy się według nich orientować".

${ }^{14}$ Z. Skorny, Aspiracje młodzieży oraz kierujące nimi prawidłowości, s. 28; J. Trempała, Deregulacja cyklu życia w planach życiowych młodzieży, Polskie Forum Psychologiczne, 2006, 11, 1, s. 116. $\mathrm{W}$ badaniach nad orientacjami przyszłościowymi młodzieży postawę tę J. Trempała opisuje jako „iluzoryczny optymizm”, kojarzony z młodzieńczym idealizmem, traktowanym jako niedojrzała postawa życiowa. 
owej aspiracji życzeniowej jest marzycielstwo, któremu nie tylko „nie towarzyszy działanie zmierzające do osiągnięcia odpowiadającego im celu", lecz najczęściej związane jest z „rzeczywistością” dalece oderwaną od rzeczywistości.

Marzenia same $\mathrm{w}$ sobie pełnią ważną funkcję w życiu psychicznym i zgodnie z wynikami badań J. Singera, przeciętny człowiek doświadcza ich każdego dnia w jednej z jej form: (1) tych pozytywnych i konstruktywnych, które twórczo oddziałują na nasze życie, ale i tych (2) wywołujących poczucie winy i wprawiających w zakłopotanie, oraz takich nad którymi (3) mamy niską kontrolę, nie panujemy nad ich treścią i nie pozwalają nam one skupić się na wykonywanych zadaniach ${ }^{15}$.

Marzycielstwo wykazuje natomiast ogromną dysproporcję między światem wyobraźni a nieadekwatnym i dalekim od niej światem rzeczywistym, przy jednoczesnym znacznym ograniczeniu oddziaływania jednego wymiaru na drugi. Rzeczywistość nie ma dostępu do wyobraźni i w związku z tym nie ma możliwości urealniania tego, co ona wytwarza, a z drugiej strony wyobraźnia nie ma dostępu do rzeczywistości, a więc możliwości uzewnętrznienia i zmiany ograniczonej rzeczywistości. Wyobraźnia marzyciela nie zmienia bowiem rzeczywistości, lecz tylko i wyłącznie negatywnie zmienia samego człowieka. Odrywa go od tego co realne, prowadząc do niedostosowania marzyciela do świata, a często także do zaniedbania swoich podstawowych obowiązków nie tylko względem siebie, ale także względem innych, $\mathrm{w}$ domu, w szkole, w pracy. Poświęcanie czasu marzeniom nie tylko alienuje od rzeczywistości, lecz w skrajnych przypadkach może nawet wywołać swoistą formę behawioralnego uzależnienia: uzależnienia od marzeń ${ }^{16}$.

Dlatego, marzycielstwo jest coraz częściej traktowane i opisywane jako zaburzenie psychiczne i w związku z tym określane w literaturze jako „nieadaptacyjne marzenia". Jest to zjawisko, któremu podlega coraz więcej dzieci i młodzieży. Są to osoby, które wyraźnie potrafią oddzielić sferę marzeń od rzeczywistości, lecz całkowicie nie panują nad swoją wyobraźnią, zarówno nad samym procesem, jego początkiem i końcem, jak i nad jej treścią, pozytywnymi lub negatywnymi doznaniami, ale przede wszystkim nie panują nad realnymi konsekwencjami w postaci zaniedbywanych relacji społecznych i obowiązków ${ }^{17}$.

${ }^{15}$ J.L. Singer, The inner world of daydreaming, New York 1975.

${ }^{16}$ I.J. Pietkiewicz i in., Maladaptive daydreaming as a new form of behavioral addiction, Journal of Behavioral Addictions, 2018, 7, 3, s. 838-843.

17 A. Schimmenti, E. Somer, M. Regis, Maladaptive daydreaming: Towards a nosological definition, Annales Médico-psychologiques, revue psychiatrique, 2019, 177, 9, s. 865-874; J. Bigelsen $\mathrm{i}$ in., Maladaptive daydreaming: Evidence for an under-researched mental health disorder, Consciousness and Cognition, 2016, 42, s. 254-266; S.I. Lindquist, J.P. McLean, Daydreaming and its correlates in an educational environment, Learning and Individual Differences, 2011, 21, 2, s. 158-167; 
Przyczyn tego upatruje się w deficytach motywacyjnych, niezdolności do samorealizacji, jak określa się to w psychologii humanistycznej. Potocznie natomiast uważa się to za brak dobrej lub silnej woli. To właśnie tego typu interpretacja zjawiska marzycielstwa, jako braku wystarczającego zaangażowania w działanie, jest też najczęściej przyczyną irytacji u rodziców, wychowawców i nauczycieli, ponieważ sytuuje przyczynę problemu w podmiocie. Uzasadnienia te stanowią jednak przykład tak zwanego podstawowego błędu atrybucji, który określa się jako "tendencję do przeceniania rozmiaru, w jakim zachowanie ludzi jest wynikiem oddziaływania dyspozycji wewnętrznych, a niedocenianie roli czynników sytuacyjnych"18.

To przenosi nas do innego pola możliwego rozumienia przyczyn marzycielstwa, gdzie upatruje się zaniechania zaangażowania $w$ realizację marzeń ze względu na zbyt małą ilość lub niską jakość bodźców zewnętrznych, lub też uważa się, że główną przyczyną są niekorzystne ograniczanie możliwości ich ekspresji i materializacja. Nierzadko wówczas można usłyszeć z ust uczniów, a nawet rodziców, że to przez „,złego" nauczyciela, system szkolny, brak pomocy dydaktycznych i tak dalej. Skrajna postać tego rodzaju interpretacji jest przejawem typowego błędu atrybucji, który zakłada, że porażki są skutkiem czynników zewnętrznych, a sukcesy przypisywane własnemu zaangażowaniu i zdolnościom.

Wykorzystując więc klasyczne ujęcia psychologiczne, przyczyn marzycielstwa można poszukać $\mathrm{z}$ jednej strony w czynnikach wewnętrznych, $\mathrm{z}$ drugiej natomiast $\mathrm{w}$ problemach deficytu zewnętrznych uwarunkowań, czyli właściwych bodźców. Do pierwszej grupy teorii zaliczyć możemy teorie psychoanalityczne, neuropsychologiczne, czy humanistyczne, do drugiej natomiast behawioralne i poznawczo-behawioralne.

Powyższe kwestie do dziś stanowią dla psychologii problemy wyrażone w nie do końca wyjaśnionej „kontrowersji: osoba - sytuacja” i kwestii dualizmu psychofizycznego. Poszukiwania ukierunkowane są na definiowanie niejasnej kategorii „wewnętrznej spójności”, jednak dla pedagogiki nie są wystarczająco użyteczne i zadowalające ${ }^{19}$.

Wspomniane powyżej klasyczne próby odpowiedzi na pytanie o przyczyny marzycielstwa mają więc z jednej strony charakter redukcjonistyczny, gdyż poszukując najprostszych uzasadnień obserwowanych zjawisk zatraca-

w Polsce istnieją nieliczne psychologiczne badania problemu „nieadaptacyjnych marzeń”, są to między innymi: Fantazjowanie i inne strategie radzenia sobie $z$ trudnościami oraz stresem - walidacja narzędzi, b.d., https:// www.e-psyche.eu/pl/projekty-w-trakcie-realizacji/marzycielstwo, [dostęp: 10.02.2021]; M. Czakon, Doktorat z marzycielstwa, 15.01.2018, https://jakdzialacskutecznie.pl/doktorat-z-marzycielstwa/, [dostęp: 15.12.2020].

${ }_{18}$ E. Aronson, T.D. Wilson, R.M. Akert, Psychologia społeczna: serce i umyst, Poznań 1997, s. 13 .

${ }^{19}$ L.A. Pervin, O.P. John, Osobowość, s. 579-581. 
ją ich złożoną istotę, a z drugiej strony, stosując założenia metodologicznego indywidualizmu, gubią z pola widzenia ich społeczny wymiar. Interesujące ujęcie tego problemu, umożliwiające przekroczenie owej swoistej aporii tego co wewnętrzne i zewnętrzne, można znaleźć w pracach L.S. Wygotskiego i badaczy rozwijających jego podejście, w ramach tak zwanej koncepcji kulturowo-historycznej.

\section{Marzycielstwo jako problem rozpadu jedności psychofizycznej}

Aby zrozumieć specyfikę podejścia kulturowo-historycznego do marzycielstwa, należy na początku przyjrzeć się podstawowym poglądom jego twórcy - L.S. Wygotskiego, dotyczącym rozwoju człowieka, w tym w szczególności rozwoju psychicznego. Twórczość “Mozarta psychologii”, jak określił go kiedyś S. Toulmin ${ }^{20}$, dlatego często określa się mianem nieklasycznego podejścia do rozwoju psychiki człowieka, ponieważ w stosunku do koncepcji przedstawianych przez innych psychologów, wyraźny staje się fakt zmiany opisu relacji jednostki z otoczeniem, w którym ona żyje i się rozwija, a także zmiana metod badawczych. Rodząca się $w$ tamtym czasie psychologia była pod silnym wpływem mocno zakorzenionego w naukach społecznych postkartezjańskiego przekonania o podziale sfery materii i ducha, ciała i psychiki. Ta swoista aporia w świetle tamtejszych poglądów była niwelowana bądź przez spirytualizację ciała, bądź materializację ducha. Psychologia jako dyscyplina akademicka od samego początku znajdowała się pod wpływem intensywnie rozwijających się nauk ścisłych, które stanowiły dla niej i dla wielu innych dziedzin swoiste kryterium „czystości” badawczej. W naukach ścisłych natomiast dominującym poglądem były ujęcia mechanistyczne, zyskujące popularność ze względu na powszechny zachwyt nad możliwościami maszyn, dzięki którym człowiek mógł tak intensywnie kontrolować i zmieniać otaczającą go rzeczywistość. Te ogólne założenia badawcze intensywnie wpłynęły również na poglądy naukowców odnośnie natury człowieka, a w szczególności na konceptualizację zjawisk psychicznych, w tym marzeń.

Wygotski od samego początku zwracał uwagę na fakt, że człowiek nie jest maszyną. Człowiek jest istotą biologiczną, a w związku z tym jego życie i rozwój ma charakter organiczny, a nie mechaniczny, a ponadto jest istotą społeczną, co oznacza, że jego istnienie i działanie są silnie powiązane i zdeterminowane kontekstem społecznym, znacznie bardziej aniżeli przedmiotami czy maszynami. Na człowieka o wiele większy wpływ ma to, co ma dla niego znaczenie, aniżeli to, co na niego silnie mechanicznie oddziałuje.

${ }^{20}$ S. Toulmin, The Mozart of Psychology, The New York Review of Books, 1978, 25, 14. 
Formuje go bardziej społeczny kontekst rozwoju ${ }^{21}$, czyli relacja psychiczna z drugim człowiekiem, aniżeli siła bodźców. Rozwój człowieka polega tutaj przede wszystkim na pogłębianiu relacji z innymi, a nie na uniezależnianiu się od innych, na rozbudowywaniu wspólnych działań, a nie separowaniu od innych. Począwszy od form biologicznych (zewnętrznych) do form psychicznych (wewnętrznych), od niższych funkcji psychicznych do wyższych funkcji psychicznych ${ }^{22}$.

Daleko odmienne jest to od tego, co dość powszechnie przyjmowano nie tylko w czasach życia Wygotskiego, ale i przyjmuje się również współcześnie, kiedy patrzy się na człowieka jako istotę dążącą do odrębności, niezależności i samowystarczalności. Teorie te zamykają człowieka, jak filozoficzną monadę, w świecie jego indywidualnych emocji, myśli i marzeń, podczas gdy największe osiągnięcia powstają i rozwijają się w relacjach społecznych, "w polu wspólnej uwagi” czy dzięki „myśleniu społecznie rekurencyjnemu”, używając terminów M. Tomasello ${ }^{23}$. Poglądy indywidualistyczne przyjmowane również współcześnie niemalże jako aksjomaty w naukach społecznych, prowadzą nie tylko do wielu błędnych wniosków na temat życia człowieka, ale skutkują konstruowaniem takich rozwiązań pedagogicznych, które nie tylko nie wspomagają rozwoju dzieci, ale go zaburzają ${ }^{24}$.

Szczególnie dobrze jest to widoczne na przykładzie analizowanego przez nas marzycielstwa. Sam w sobie niezbędny i immanentnie ludzki fenomen wyobraźni i marzeń, rozbudzany na wiele sposobów przez rodziców i nauczycieli, lecz bez uwzględnienia społecznego kontekstu jego rozwoju, nie tylko jemu nie służy, ale paradoksalnie przyczynia się do jego rozkładu ${ }^{25}$.

Jeżeli przyjmiemy, że marzycielstwo jest najbardziej wyraźnym przykładem „rozkładu” relacji między wyobraźnią i rzeczywistością, to przywrócenie jej wymaga odnalezienia najmniejszych elementów posiadających cechy zarówno wyobraźni, jak i rzeczywistości. Należałoby więc poszukać takich najmniejszych jednostek analizy badanej rzeczywistości, które nie tracą cech

${ }^{21}$ L.I. Bozhovich, The social situation of child development, Journal of Russian \& East European Psychology, 2009, 47, 4, s. 59-86; P. Gąsiorek, B. Zamorska, Nauczyciel i uczeń w zagrożeniu zombifikacją. Problem motywu i motywacji w perspektywie kulturowo-historycznej, Edukacja, 2019, 149,2 , s. 6-22.

22 Л.С. Выготский, Лекции по педологии, Ижевск 2001; tenże, Problem wieku rozwojowego, [w:] Wybrane prace psychologiczne II: dzieciństwo i dorastanie, red. A. Brzezińska, M. Marchow, Poznań 2002, s. 78-79; M. Bredikyte, Akt kulturowego upośredniania w zabawie dzieci, Forum Oświatowe, 2012, 47, 2, s. 78-79.

${ }^{23}$ M. Tomasello, Historia naturalna ludzkiego myślenia, Kraków 2015.

${ }^{24}$ P. Gąsiorek, B. Zamorska, Zmiana działalności młodzieży zagrożonej wykluczeniem społecznym. Badania interwencyjne w kulturowo-historycznej teorii dziatalności, Przegląd Pedagogiczny, 2017, 1, s. 96-114; tenże i taże, Nauczyciel i uczeń w zagrożeniu zombifikacją.

25 Л.С. Выготский, Лекции по педологии, s. 34; tenże, Wybrane prace psychologiczne, Warszawa 1971, s. 166-167. 
całości, ale też zawierają w sobie integralne, najbardziej charakterystyczne elementy każdej z części składowych. Tym, co łączy oba bieguny, według Wygotskiego, jest właśnie twórczość, ponieważ zawiera $\mathrm{w}$ sobie elementy wyobrażeniowe, jak też elementy pochodzące z rzeczywistości. To właśnie twórczość według niego jest procesem, który przekształca wyobraźnię w rzeczywistość oraz stanowi podstawowe źródło pobudzające i ubogacające działalność wyobraźni przez fakty, zjawiska, osoby oraz doświadczenia przeżywane w kontakcie z rzeczywistością. Można więc powiedzieć, że rzeczywistość rozbudza marzenia i wyobraźnię, a wyobraźnia zmienia rzeczywistość. W przypadku marzycielstwa mamy więc do czynienia z sytuacją, w której następuje rozerwanie, a nawet zablokowanie drogi łączącej wyobraźnię z rzeczywistością.

Rozpoznanie i zrozumienie przyczyn nieadaptacyjnych marzeń, z perspektywy kulturowo-historycznej, wymaga zrekonstruowania tak zwanego „ogólnego prawa genetycznego", które zdaniem Wygotskiego stanowi podstawową zasadę rozwoju psychiki człowieka. Ogólne prawo genetyczne głosi, że aby człowiek mógł rozwinąć wyższe funkcje psychiczne, do których należy także proces twórczy, powinien przeżyć go najpierw w relacji z drugim człowiekiem. Bez tego społecznego doświadczenia niemożliwe jest pojawienie się rozwoju psychicznego $w$ jego najbardziej wysublimowanych formach, czyli w postaci wyższych funkcji psychicznych. Wyższą funkcją psychiczną, w intersującym nas kontekście marzycielstwa, jest pojawienie się wyobraźni twórczej.

Wyobraźnia dziecka jest niezwykle rozwinięta, lecz - jak zauważa Wygotski - ma bardzo mało cech charakterystycznych dla twórczej wyobraźni. Ta ostatnia bowiem tym się różni od wyobraźni dziecięcej, że urzeczywistnia w społecznym kontekście rozwoju to, co zostało wymarzone, wyobrażone. Wyobraźnia twórcza materializuje myśli i wyobrażenia, wciela to co psychiczne $w$ to co materialne, a w ten sposób zmienia rzeczywistość. Z perspektywy badanego przez nas zjawiska można więc powiedzieć, że przejście od marzeń do rzeczywistości polega na opanowaniu procesu twórczego. To natomiast jest możliwe dla dziecka wtedy i tylko wtedy, gdy najpierw będzie mogło tego doświadczyć w relacji z dorosłym i razem z dorosłym. Tworząc psychologiczną jedność z dorosłym, rodzicem czy nauczycielem, z jednej strony pokazuje mu świat swoimi oczami, ale też dziecko uczy się patrzeć na świat oczami dorosłego. Nie tylko przeżywa swoje marzenia, ale uczy się je widzieć z zewnątrz, oczami dorosłego, tworzy proces metapoznawczy, czyli uświadamia je sobie. Kierowane po świecie swoich marzeń przez dorosłego i wspomagane przez niego, uczy się je kontrolować. Przechodzi od mimowolnych procesów myślowych i marzeń do procesów dowolnych. Prowadzone przez dorosłego, uczy się prowadzić samo siebie. Uczy się metod kierowania sobą, swoimi myślami i marzeniami. Przechodzi od mimowolnych wytworów ma- 
rzeń do wytworów dowolnych, co jest pierwszym krokiem przekształcenia się marzenia w twórczą wyobraźnię. Dziecko panując nad swoimi myślami, pragnieniami, świadomie i według własnej woli kieruje nimi i je przekształca. Nie jest jednak samo w stanie tego zrobić, potrzebuje pomocy w opanowaniu swoich marzeń. Potrzebuje pomocy dorosłego do samopomocy ${ }^{26}$.

Bardzo dobrym tego przykładem jest stosunek Goluma, jednego z głównych bohaterów powieści J.R. Tolkiena, do „pierścienia”. Pierścień sam w sobie będący kawałkiem metalu, w marzeniach, w świecie wyobrażonym, staje się skarbem, który panuje nad Golumem i dla którego on sam był gotów poświęcić nawet własne życie. Ta fantastyczna, żeby nie powiedzieć marzycielska, historia kryje jednak pewien sekret, a mianowicie, żeby pierścień utracił swoją moc, trzeba wejść do Mordoru, krainy, nad którą nie ma się żadnej władzy. Jednak może to zrobić tylko ktoś, kto nie poddaje się wyimaginowanej władzy pierścienia. Paradoks więc polega na tym, że to wejście w świat marzeń dziecka pomaga mu je kontrolować, a nie ucieczka czy negacja owych marzeń. Każdy człowiek jest istotą psychiczną, wyobrażającą, pełną marzeń i ów wewnętrzny świat jest dla nas równie realny, a często bardziej, niż ten materialny. Społecznym kontekstem rozwoju marzyciela jest właśnie psychologiczna obecność dorosłych w świecie jego marzeń. Stanowi istotny warunek do tego, aby dziecko nauczyło się od dorosłego je kontrolować, a później twórczo przekształcać. Podkreślanie wartości tego co realne, kosztem świata marzeń, może prowadzić jedynie do alienacji i samotności przeżywanej głęboko w świecie marzeń, zgodnie ze słowami powszechnie znanej piosenki N. Kukulskiej: „Im więcej Ciebie, tym mniej. Bardziej to czuję niż wiem...”.

\section{Zakończenie}

Marzenia i wyobraźnia są tak wyjątkowo rozwiniętym fenomenem jedynie u człowieka. Dzięki nim nie tylko adaptuje się on do rzeczywistości, ale może tę rzeczywistość zmieniać, a przede wszystkim tworzyć. Twórczość to największa kompetencja, jaką człowiek posiada i jaką powinien rozwijać. Niezdolność do tworzenia jest swoistym zubożeniem człowieczeństwa. Przykładem tego jest analizowane powyżej marzycielstwo, które mimo rozwiniętej wyobraźni cechuje ograniczona ekspresja. Marzenia zawsze są początkiem czegoś nowego.

${ }^{26}$ P. Hakkarainen, Podejście kulturowo-historyczne do rozwoju samoregulacji u dzieci w zabawie i uczeniu sie, [w:] Nauczanie rozwijajace we wczesnej edukacji wedtug Lwa S. Wygotskiego. Od teorii do zmiany w praktyce, red. E. Filipiak, Bydgoszcz 2015, s. 67-110; B. Smykowski, P. Kleka, Skala Spontaniczność-Reaktywność (S-RS): podstawowe zatożenia i badania, Polskie Forum Psychologiczne, 2017, 22, s. 116-138. 
R. Lewandowski otrzymując "The Best FIFA Football Awards 2020”, ujął to w następujący sposób: „To niesamowita nagroda za lata ciężkiej pracy i przypomnienie, by nigdy nie przestawać marzyć" ${ }^{27}$. Wskazał jednak wówczas dwóch "ojców” swojego sukcesu: marzenia i pracę. Marzenia i praca są to więc wewnętrznie połączone fenomeny, ponieważ konstruowanie marzeń wymaga ogromnego wysiłku, a zaangażowanie w pracę jest możliwe tylko wówczas, kiedy zachowamy w wyobraźni wymarzony cel. Zarówno podczas jednej, jak i drugiej działalności dziecko potrzebuje obecności dorosłego, który pomoże formować $w$ marzenia dziecięce pragnienia i zmaterializować je w rzeczywistości. Przeakcentowanie marzeń, z jednej strony, i koncentracja jedynie na wysiłku wkładanym w świat realny, $\mathrm{z}$ drugiej, to podstawowe przyczyny rozkładu organicznej jedności procesu twórczego. Największym błędem jest jednak uznanie, że zarówno jeden jak i drugi element są to procesy samorealizacyjne, ponieważ każdy z nich ma naturę społeczną. Wymagają one, mówiąc kategoriami opisanymi przez Tomasello, korzystania z „myślenia społecznie rekurencyjnego", którego dziecko uczy się zawsze od dorosłych, na ich przykładzie, i w „polu wspólnej uwagi”. Tak wygląda „historia naturalna ludzkiego myślenia"28, które tak ujęte może uniknęłoby krytyki Kanta, a przede wszystkim nie stało się przyczyną pojawiania się u dzieci i młodzieży „nieadaptacyjnych marzeń". W tej organicznej jedności między ludźmi zarówno we (współ)marzeniach, jak i (współ)pracy rozwija się życie psychiczne człowieka. Owa jedność nie ma charakteru statycznego i topograficznego, lecz stanowi dynamiczne kontinuum, po którym przesuwa się działalność psychiczna człowieka bądź w jedną, bądź w drugą stronę: od rzeczywistości do marzeń i vice versa. Każda sztywność, kompulsywne trzymanie się jednego z biegunów może stanowić istotne zagrożenie dla potencjału rozwojowego człowieka.

Marzycielstwo jako jeden z powyższych biegunów można uznać więc za pewne „wykolejanie” się człowieka z drogi od marzeń do rzeczywistości i z rzeczywistości do marzeń. Marzycielstwo zrywa relację sfery motywacyjnej z rzeczywistością, w której marzenie może się urealnić. Staje się swoistym bezdrożem lub „drogą donikąd”. Myśli takiej osoby przypominają nasiona, które zleciały z drzewa pod wpływem powiewu wiatru, a gnane nim padają na przypadkowe miejsca. Tylko przy odrobinie szczęścia mają szansę na rozwój, ponieważ wymagają zakorzenienia poza światem marzeń, muszą być „posiane w dobrej ziemi”, otoczone odpowiednią opieką i wsparciem. To metaforyczne ujęcie kryje w sobie wiele prawdy, ponieważ organiczny charakter

${ }^{27}$ R. Lewandowski, “The Best FIFA Football Awards 2020”, 17.12.2020, https:/ /www.instagram.com/p/CI6X7_KB47P/, [dostęp: 18.12.2020].

${ }_{28}$ M. Tomasello, Historia naturalna ludzkiego myślenia. 
rozwoju dzieci i młodzieży nie dokonuje się samoistnie, nie samorealizuje się, lecz wymaga podobnych zabiegów opiekuńczych i wychowawczych.

A. Zaporożec, uczeń Wygotskiego, podejmując tę problematykę, pisze, że w tym przypadku

marzenie odrywa się od rzeczywistości i staje się przeszkodą w działalności człowieka. Są ludzie, którzy marzeniem zastępują realne czyny, szukają w marzeniach spełnienia swych pragnień. Ludzi takich nazywa się „bezpłodnymi marzycielami”"29.

Owa „marzycielska bezpłodność”, opisywana w niniejszym tekście jako marzycielstwo czy też nieadaptacyjne marzenia, często przyjmuje kształt nawet do szczegółów doprecyzowanej koncepcji. Wykorzystuje rozbudowane konstrukty wyobrażeniowe, a czasami nawet naukowe metapojęcia. Jednak ukazane przez J.H. Andersena uszyte najpiękniejsze "szaty" nie są w stanie okryć nagości nawet cesarza. Podobnie „rzekoma ciąża”, przy rozwiniętej erudycji i retorycznej biegłości, ze względu na ratum sed non consummatum, nie uzyska swego ucieleśnienia. Potrzebne jest (współ)marzenie i (współ) działanie, dzięki czemu zostanie przekroczona dychotomia wyobraźnia-rzeczywistość, zostanie uprzedmiotowione wyobrażenie, a rzeczywistość będzie wymarzona.

\section{BIBLIOGRAFIA}

Aronson E., Wilson T.D., Akert R.M., Psychologia społeczna: serce i umyst, Zysk i S-ka Wydawnictwo, Poznań 1997.

Bartczak A., Wontorczyk A., Strzelecki M., Banaś M., Prokrastynacja zawodowa jako forma ekologii pracy i jej wspótczesne uwarunkowania, Czasopismo Psychologiczne, 2018, 24, 2.

Bigelsen J., Lehrfeld J.M., Jopp D.S., Somer E., Maladaptive daydreaming: Evidence for an under-researched mental health disorder, Consciousness and Cognition, 2016, 42.

Bozhovich L.I., The social situation of child development, Journal of Russian \& East European Psychology, 2009, 47, 4.

Bredikyte M., Akt kulturowego upośredniania w zabawie dzieci, Forum Oświatowe, 2012, 47, 2.

Butcher J.N., Hooley J.M., Mineka S., Psychologia zaburzeń: DSM - 5, Gdańskie Wydawnictwo Psychologiczne, Sopot 2020.

Czakon M., Doktorat z marzycielstwa, 15.01.2018, https:/ /jakdzialacskutecznie.pl/doktorat-z-marzycielstwa/, [dostęp: 15.12.2020].

Doroszewski W., Marzycielstwo, b.d., https://sjp.pwn.pl/slowniki/marzycielstwo.html, [dostęp: 15.12.2020].

Dryll E., Prokrastynacja: dlaczego nadal wiemy za mało?, Psychologia Wychowawcza, 2017, 54.

Fantazjowanie i inne strategie radzenia sobie z trudnościami oraz stresem - walidacja narzędzi, b.d., https:// www.e-psyche.eu/pl/projekty-w-trakcie-realizacji/marzycielstwo, [dostęp: 10.02.2021].

29 A. Zaporożec, Psychologia, Warszawa 1955, s. 110. 
Gąsiorek P., Nauczyciel i uczeń w zagrożeniu zombifikacją. Problem motywu i motywacji w perspektywie kulturowo-historycznej, Edukacja, 2019, 149, 2.

Gąsiorek P., Zamorska B., Zmiana działalności młodzieży zagrożonej wykluczeniem społecznym. Badania interwencyjne w kulturowo-historycznej teorii działalności, Przegląd Pedagogiczny, 2017, 1.

Hakkarainen P., Podejście kulturowo-historyczne do rozwoju samoregulacji u dzieci w zabawie i uczeniu się, [w:] Nauczanie rozwijajace we wczesnej edukacji wedtug Lwa S. Wygotskiego. Od teorii do zmiany w praktyce, red. E. Filipiak, Agencja Reklamowo-Wydawnicza ArtStudio, Bydgoszcz 2015.

Jarmużek J., Uwarunkowania aspiracji edukacyjno-zawodowych człowieka, Acta Universitatis Nicolai Copernici. Pedagogika, 2018, 36, 2.

Jarosz M., Acedia jako zagrożenie duchowe, Zeszyty Formacji Katechetów, 2020, 2-3.

Kałużna-Wielobób A., Typy „marzycielek” wśród kobiet w wieku średnim, Roczniki Psychologiczne, 2009, 12, 2.

Kałużna-Wielobób A., Marzenia a cechy osobowości licealistek $i$ studentek, Studia Psychologica: Theoria et praxis, 2012, 12, 1.

Kałużna-Wielobób A., Marzenia wspótczesnych kobiet w różnych okresach rozwojowych, Teraźniejszość - Człowiek - Edukacja, 2013, 16, 1(61).

Kant I., Co to znaczy orientować się w myśleniu?, Principia, 2012, 2003, 36.

Kozielecki J., Smutek spetnionych baśni, Wydawnictwo Literackie, Kraków 1985.

Lewandowski R., “The Best FIFA Football Awards 2020”, 17.12.2020, https:/ /www.instagram.com/p/CI6X7_KB47P/, [dostęp: 18.12.2020].

Lindquist S.I., McLean J.P., Daydreaming and its correlates in an educational environment, Learning and Individual Differences, 2011, 21, 2.

Markiewicz K., Prokrastynacja i prokrastynatorzy. Definicja, etiologia, epidemiologia i terapia, Annales Universitatis Mariae Curie-Skłodowska - Paedagogia-Psychologia, 2019, 31, 3.

Pearlman-Avnion S., Harduf R., Prokrastynacja, perfekcjonizm oraz poczucie umiejscowienia kontroli w kontekście akademickim, Szkoła Specjalna, 2019, 80.

Pervin L.A., John O.P., Osobowość: teoria i badania, Wydawnictwo Uniwersytetu Jagiellońskiego, Kraków 2002.

Piasecka M., Otwieranie świata edukacji - w stronę potencjalności, Podstawy Edukacji, 2009, 2.

Piasecka M., Marzenia sprawcze i ponadosobiste w perspektywie badań narracyjnych, Podstawy Edukacji, 2012, 5.

Piasecka M., Marzenia w narracji autobiograficznej. Między porządkiem a chaosem, Podstawy Edukacji, 2015, 8.

Piasecka M., (Geo)poetyka marzenia. Utopia - heterotopia - trzecia przestrzeń, [w:] Utopia a edukacja, t. IV, red. R. Włodarczyk, Instytut Pedagogiki Uniwersytetu Wrocławskiego, Wrocław 2020.

Piasecka M., Topoanaliza autobiograficzno-symboliczna jako metoda badania (nie)dokończonych marzeń, Studia Edukacyjne, 2020, 56.

Pietkiewicz I.J., Nęcki S., Bańbura A., Tomalski R., Maladaptive daydreaming as a new form of behavioral addiction, Journal of Behavioral Addictions, 2018, 7, 3.

Schimmenti A., Somer E., Regis M., Maladaptive daydreaming: Towards a nosological definition, Annales Médico-psychologiques, revue psychiatrique, 2019, 177, 9.

Singer J.L., The inner world of daydreaming, Harper \& Row, New York 1975.

Skorny Z., Aspiracje młodzieży oraz kierujące nimi prawidłowości, Zakład Narodowy im. Ossolińskich, Wrocław 1980.

Smykowski B., Kleka P., Skala Spontaniczność-Reaktywność (S-RS): podstawowe zatożenia i badania, Polskie Forum Psychologiczne, 2017, 22. 
Stec Ł., Acedia a poszukiwanie nieokreślonego. Między melancholia, nudą a utopia, Młoda Humanistyka, 2019, 14, 1.

Syrek E., Aspiracje życiowe młodzieży niedostosowanej społecznie, Uniwersytet Śląski, Katowice 1986.

Szacki J., Spotkania z utopia, Wydawnictwo Sic!, Warszawa 2000.

Śliwerski B., Utopia edukacyjnych utopii, [w:] Pedagogiczne konteksty społecznych wyobrażeń świata możliwego, t. 2 - Utopia a edukacja, red. R. Włodarczyk, Instytut Pedagogiki Uniwersytetu Wrocławskiego, Wrocław 2017.

Tomasello M., Historia naturalna ludzkiego myślenia, Wydawnictwo Copernicus Center Press, Kraków 2015.

Toulmin S., The Mozart of Psychology, The New York Review of Books, 1978, 25, 14.

Trempała J., Deregulacja cyklu życia w planach życiowych młodzieży, Polskie Forum Psychologiczne, 2006, 11, 1.

Wesoły M., Platon i Arystoteles w ocenie Kanta, Przegląd Filozoficzny. Nowa Seria, 1997, 23, 3. Wygotski L., Wybrane prace psychologiczne, Państwowe Wydawnictwo Naukowe, Warszawa 1971.

Выготский Л.С., Лекиии по педологии, Удмуртский университет, Ижевск 2001.

Wygotski L.S., Problem wieku rozwojowego, [w:] Wybrane prace psychologiczne II: dziecinstwo i dorastanie, red. A. Brzezińska, M. Marchow, Zysk i S-ka Wydawnictwo, Poznań 2002.

Zaporożec A., Psychologia, Państwowe Zakłady Wydawnictw Szkolnych, Warszawa 1955. 